\title{
Analysis of Internet Addiction Levels of University Students in Terms of the State of Doing Sport
}

\author{
Menderes KABADAYI
}

Yasar Dogu Sports Sciences Faculty, Ondokuz Mayzs University, Samsun, Turkey.

Email:menderes@omu.edu.tr.Tel: +905056055506

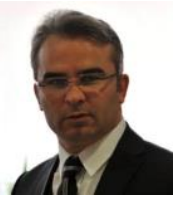

\section{Abstract}

The aim of the present study is to examine the internet addiction levels of university students in terms of the state of doing sport and different variables. A total of 300 students, 132 male and 168, studying in Samsun Ondokuz Mayıs University participated in the study. Internet Addiction Scale which was developed by Günüç and Kayri (2010) and which had four sub-dimensions (withdrawal, controlling difficulty, disorder in functionality and social isolation) was used. SPSS 22.0 program was used for the statistical analysis. Significance was found in the sub-dimensions of withdrawal and social isolation in terms of the variable of gender $(p<0.05)$ and in the sub-dimension of social isolation in terms of the variables of faculty and the state of doing sport regularly $(\mathrm{p}<0.05)$. It can be seen that internet addiction levels were similar in all sub-dimensions except for social isolation, while they were found to be different in the sub-dimension of withdrawal in terms of the variable of gender. This result is thought to be associated with the fact that students who do sport regularly and those attending sport sciences faculty are not exposed to social isolation due to sport and that they lead more social lives when compared with the students of other faculties. In terms of the variable of gender, it is thought that the reason why female students had higher withdrawal levels can be due to the fact that men can act more comfortably in social life.

Keywords: Internet addiction, University student, Sport.

Citation | Menderes KABADAYI (2020). Analysis of Internet Addiction Levels of University Students in Terms of the State of Doing Sport. Asian Journal of Education and Training, 6(2): 181185.

History:

Received: 20 December 2019

Revised: 2 February 2020

Accepted: 9 March 2020

Published: 30 March 2020

Licensed: This work is licensed under a Creative Commons

Attribution 3.0 License (cc)

Publisher: Asian Online Journal Publishing Group
Funding: This study received no specific financial support.

Competing Interests: The author declares that there are no conflicts of interests regarding the publication of this paper.

Transparency: The author confirms that the manuscript is an honest, accurate, and transparent account of the study was reported; that no vital features of the study have been omitted; and that any discrepancies from the study as planned have been explained.

Ethical: This study follows all ethical practices during writing.

\section{Contents}

1. Introduction

3. Results. 


\section{Contribution of this paper to the literature}

This study contributes to existing literature by examining the internet addiction levels of university

students in terms of the state of doing sport and different variables.

\section{Introduction}

One of the factors that have influenced the lives of people in terms of information technology with the advancements in technology is the widespread use of the internet (Balci \& Gülnar, 2009). Since the beginning of 1990s, the use of internet has become such that people have been unable to keep themselves from using this mass media and connecting the internet (Wang, 2001). The internet, which was originally thought to be designed to facilitate receiving information, interpersonal communication and a great number of commercial and institutional businesses, has become a mass media tool with which people can easily handle almost all of their businesses.

Today, internet use has reached huge dimensions. According to the data of Internet World Stats, while there were around 300 million internet users in the world in 2000, the number reached 1,5 billion in 2009 and according to mid 2014 data, the number of internet users in the world exceeded 3 billion. Nalwa and Anand (2003) reported that with the significance of internet use and this great increase in the amount of online use, internet addiction has begun to be seen more frequently in the society.

The fact that the internet has entered our lives so much has also caused it to enter the education and psychology literature with the effects it causes on the individual. It was suggested in a study by Goldberg (1995) that internet can cause addiction, and the first work-related definition of addiction was made by Young (1996). In addition, a great number of the studies conducted showed that most of the addicts prioritize social relationships and choose services such as chatting, meeting, role-playing, forum, mail, etc., which include interaction (Davis, 2001; Song, Larose, Eastin, \& Lin, 2004; Young., 1997). In addition, it was also found that individuals with internet addiction frequently addressed the variable of loneliness and thus their addiction increased (Kraut et al., 1998; Subrahmanyam \& Lin, 2007).

Researchers have reported that internet use and addiction is very common especially in high school and university students and that this situation has a negative effect on their psychological and physical development and social relationships and causes a decrease in their academic achievement (Cengizhan, 2005). In addition to students' academic achievement, it is reported that the source of internet addiction can emerge as a result of one or more characteristics of internet use which includes processes such as writing, communication medium, lack of face to face communication, internet content or online social activities (instant messaging, online games) and that this situation can also cause problems such as communication and social skills and also some physical problems depending on the immobility during internet use (Leung, 2004; Ozgen \& Bavll, 2017).

Sport is among the most basic physical activities of our day. Ten thousands of people doing sport in various parts of the world every day are interested in sportive activities. Even though we are not aware of it, sport activities have always been intertwined with vital activities and social life in almost every period of human history. Thus, it is not very possible to take sport out of social life (Cavusoglu., Yılmaz, Kabadayı, Abacı, \& Tasmekteplıgıl, 2017; Dever, 2010; Dogan., Yilmaz, Kabadayi, \& Mayda, 2018; Kabadayı., Yılmaz, \& Mayda, 2018; Tekeli., 2017). When these significant effects of sport on social life are considered, the thought that individuals who do sport regularly can get away from all factors that can cause addiction and that they can be healthier both physically and psychologically when compared with individuals who do not do sports comes to the forefront.

Based on all this information, the aim of the present study is to analyze the internet addiction levels of university students from different faculties who are doing sport regularly and those who are not. The hypothesis of our study is that the students who do sport regularly will have lower internet addiction when compared with the students who do not.

\section{Material and Method}

\subsection{Study Design}

A total of 300 students, 132 male and 168 female, studying in different departments of Samsun Ondokuz Mays University participated in the study. In the study, The Profile of Internet Dependency and Internet Addiction Scale which was developed by Günüç and Kayri (2010) and which had four sub-dimensions (withdrawal, controlling difficulty, disorder in functionality and social isolation) was used. The subjects in the study filled in voluntary participation form and it was emphasized that it was important for them to read the questions and fill in the questionnaire form carefully for the reliability and validity of the study. The subjects' states of doing regular sport and some of their demographic information were found with the personal information form prepared by the author.

\subsection{Internet Addiction Scale}

In the study, The Profile of Internet Dependency and Internet Addiction Scale which was developed by Günüç and Kayri (2010) and which had 35 items and four sub-dimensions (withdrawal, controlling difficulty, disorder in functionality and social isolation) was used. According to the analysis results conducted to test the reliability level of the scale used in the study, Cronbach alpha coefficients were found as 0.78 (withdrawal), 0.81 (controlling difficulty) 0.73 (disorder in functionality) and 0.83 (social isolation). In addition, total internal coefficient of the scale was found as 0.78 . These results show that the results of the scale are acceptable.

\subsection{Data Analysis}

Statistical analyses were conducted with SPSS version 22.0 software. Shapiro-Wilk test was used to analyze normality assumption. In case of variables which were not normally distributed, groups of two were analyzed with Mann Whitney U test, while groups of more than two were analyzed with Kruskall Wallis and Chi-Square tests. A $\mathrm{p}$ value of less than 0.05 was assessed as statistically significant. 


\section{Results}

Table-1. Descriptive statistics of the participants

\begin{tabular}{l|c|c}
\hline Gender & $\mathbf{N}$ & $\mathbf{\%}$ \\
\hline Male & 132 & 44.0 \\
\hline Female & 168 & 56.0 \\
\hline Age & Frequency & 37.7 \\
\hline $17-20$ & 113 & 57.3 \\
\hline $21-24$ & 172 & 5.0 \\
\hline 25 and older & 15 & $\%$ \\
\hline Faculty & Frequency & 44.7 \\
\hline Sport Sciences & 134 & 55.3 \\
\hline Other faculties & 166 & $\%$ \\
\hline State of doing sport regularly & Frequency & 49.7 \\
\hline Yes & 149 & 50.3 \\
\hline No & 151 & 100.0 \\
\hline Total & 300 & \\
\hline
\end{tabular}

Note: N:Number of Students, \%: percentage distribution of participants.

Table-2. Comparison of internet addiction levels of the participants in terms of gender.

\begin{tabular}{l|c|c|c|c|c|c}
\hline Sub-dimensions & Gender & Mean & Std & Median & Std. Test Sta. & p \\
\hline Withdrawal & Male & 35.6515 & 8.9758 & 163.22 & -2.254 & 0.024 \\
\hline & Female & 33.5952 & 9.1868 & 140.50 & & \\
\hline Controlling difficulty & Male & 37.9015 & 8.0645 & 159.75 & -1.639 & 0.101 \\
\hline & Female & 36.3988 & 8.4387 & 143.23 & & \\
\hline Disorder in functionality & Male & 27.4470 & 6.3502 & 146.19 & 0.767 & 0.443 \\
\hline & Female & 28.0060 & 6.2660 & 153.89 & & \\
\hline Social Isolation & Male & 28.2273 & 6.5436 & 137.39 & 2.333 & $\mathbf{0 . 0 2 0}$ \\
\hline & Female & 29.7917 & 5.9998 & 160.80 & & \\
\hline
\end{tabular}

According to the Mann-Whitney $U$ test results, significant difference was found between genders in the subdimensions of withdrawal and social isolation $(p<0.05)$. No difference was found in the sub-dimensions of controlling difficulty and disorder in functionality ( $>>0.05)$ Table 2.

Table-3. Comparison of internet addiction levels of the participants in terms of age groups.

\begin{tabular}{l|c|c|c|c|c|c}
\hline Sub-dimensions & Age groups & Mean & Std & Median & Chi square & p \\
\hline Withdrawal & $17-20$ & 33.8053 & 8.7616 & 141.50 & 2.268 & 0.322 \\
\hline & $21-24$ & 34.8198 & 9.4632 & 154.90 & & \\
\hline Controlling difficulty & $25+$ & 36.0667 & 8.1981 & 167.93 & & 0.324 \\
\hline & $17-20$ & 37.4248 & 7.9774 & 152.79 & & \\
\hline & $21-24$ & 36.7733 & 8.5348 & 148.28 & & \\
\hline Disorder in functionality & $25+$ & 37.6000 & 8.2876 & 158.63 & & 0.741 \\
\hline & $17-20$ & 27.8496 & 6.4201 & 152.66 & 0.601 & \\
\hline & $21-24$ & 27.6453 & 6.1821 & 147.89 & & \\
\hline Social isolation & $25+$ & 24.4000 & 7.0791 & 164.13 & & 0.604 \\
\hline & $17-20$ & 29.2035 & 6.6549 & 156.16 & 1.008 & \\
\hline
\end{tabular}

No statistically significant difference was found between the internet addiction levels of the participants in terms of age groups ( $>>0.05)$ Table 3 .

Table-4. Comparison of internet addiction levels of the participants in terms of faculties.

\begin{tabular}{l|c|r|r|r|r|r}
\hline Sub-dimensions & Faculty & Mean & $\begin{array}{c}\text { Standard } \\
\text { deviation }\end{array}$ & Mean rank & $\begin{array}{c}\text { Std. Test } \\
\text { Sta. }\end{array}$ & p \\
\hline Withdrawal & Sport sciences & 34.3731 & 10.1742 & 150.13 & -0.082 & 0.934 \\
\hline & Other faculties & 34.6024 & 8.2351 & 150.96 & & \\
\hline Controlling difficulty & Sport sciences & 36.1194 & 9.4758 & 154.76 & 0.947 & 0.344 \\
\hline & Other faculties & 37.8193 & 7.1446 & 145.23 & & \\
\hline Disorder in functionality & Sport sciences & 26.7910 & 6.9445 & 158.79 & 1.849 & 0.065 \\
\hline Social isolation & Other faculties & 28.5422 & 5.6253 & 140.24 & & \\
\hline & Sport sciences & 27.4701 & 7.1574 & 166.03 & 3.470 & $\mathbf{0 . 0 0 1}$ \\
\hline & Other faculties & 30.4217 & 5.1301 & 131.26 & & \\
\hline
\end{tabular}

According to Mann-Whitney U test results, statistically significant difference was found in social isolation subdimension of the participants in terms of the participants' faculties $(\mathrm{p}<0.05)$. No significance was found in other sub-dimensions ( $p>0.05)$ Table 4. 
Table-5. Comparison of internet addiction levels of the participants in terms of the state of doing sport regularly.

\begin{tabular}{l|c|c|c|c|c|c}
\hline Sub-dimensions & $\begin{array}{c}\text { State of doing } \\
\text { sport regularly }\end{array}$ & Mean & $\begin{array}{c}\text { Standard } \\
\text { deviation }\end{array}$ & Mean Rank & $\begin{array}{c}\text { Std. Test } \\
\text { Sta. }\end{array}$ & p \\
\hline Withdrawal & Yes & 34.3624 & 9.6781 & 150.12 & 0.075 & 0.941 \\
\hline Controlling difficulty & No & 34.6358 & 8.8996 & 150.87 & & \\
\hline & Yes & 36.7517 & 9.1259 & 151.44 & -0.186 & 0.853 \\
\hline Disorder in functionality & No & 37.3642 & 7.4049 & 149.58 & & \\
\hline & Yes & 27.4832 & 6.7530 & 149.11 & 0.277 & 0.782 \\
\hline Social isolation & No & 28.0331 & 5.8257 & 151.87 & & 2.149 \\
\hline & Yes & 28.2550 & 6.7465 & 139.72 & $\mathbf{0 . 0 3 2}^{*}$ \\
\hline
\end{tabular}

Note: ${ }^{*} \mathrm{p}<0.05$

Mann-Whitney $\mathrm{U}$ test results showed statistically significant difference in social isolation sub-dimension in terms of the state of doing sport regularly $(\mathrm{p}<0.05)$. No statistical significance was found in other sub-dimensions $(\mathrm{p}>0.05)$ Table 5 .

\section{Discussion and Conclusion}

When the major results of the present study were analyzed, significance was found in withdrawal and social isolation sub-dimensions in terms of the variable of gender $(\mathrm{p}<0.05)$ and in only social isolation sub-dimension in terms of the variables of faculty and the state of doing regular sport $(\mathrm{p}<0.05)$. No significance was found in any of the sub-dimensions in terms of the variable of age $(p>0.05)$.

When it is considered that a great number of individuals from all age groups are either addicted to the internet or inclined to addiction, a great number of researchers conducting studies especially in the areas of psychology and education have started to carry out researches on internet addiction (Chou \& Hsiao, 2000; Chou., Condron, \& Belland, 2005; Lin \& Tsai, 2002; Morahan-Martin \& Schumacher, 2000). Studies conducted especially on university students have shown that students have an excessive desire to stay online and that this situation causes problems in their relationships (Can \& Tozoğlu, 2009). Studies conducted have shown that when compared with female students, male students have high scores almost in all sub-dimensions of internet addiction (Jiang, 2014; Kır \& Sulak, 2014; Soydan, 2015; Willoughby, 2008). The first study conducted on internet addiction in university students was by Scherer (1997) and the results of this study showed that male students were more addicted than female students, while there were no differences between the students in the non-addicted group in terms of the use of internet. When this result is considered, it can be seen that especially male students are inclined to internet addiction. However, in terms of social isolation, the results of the present study showed that when compared with male students, female students were exposed to social isolation as their dependence increased and it was thought that their tendency for alienation towards the social environment would increase consequently. Young. (1998) stated that just like other addictions, internet addiction also caused familial, personal and professional problems. It is a known fact that the most important symptoms of internet addicts are complaints such as fatigue, disturbed sleep and not being able to socialize. In addition, it was reported that internet addicts generally used communication function oriented internet, while individuals who were not addicts used the internet for purposes of getting informed and work related purposes (Balci \& Gülnar, 2009). Yuen and Lavin (2004) stated that one of the most important reasons for expulsion from school was internet addiction in university students.

When the positive effects of sport for various addictions and its contribution to the socialization of individuals are considered, the results of the present study also showed that the students who were doing sport regularly had lower addiction levels when compared with students who were not doing sport regularly. Although there are limited numbers of studies conducted on the internet addiction of individuals who do sport regularly, similar to the results of the present study, these studies also show that individuals not doing sport regularly have higher addiction scores (Can \& Tozoğlu, 2009; Özdemir, 2016). These results show that sport has positive effects on the internet addiction of individuals and especially university students and for this reason, it can be clearly seen that students should be encouraged to do sports in order to save them from this addiction and to increase their beneficial internet use. Encouraging students to do sport through communities and clubs in universities and other institutions will be an important factor in preventing the addiction and it is thought that this way students will become healthier individuals both physically and mentally.

\section{References}

Balci, S., \& Gülnar, B. (2009). Internet addiction and internet addiction profile among university students. Selcuk University Faculty of Communication Academic Journal, 6(1), 5-22.

Can, H. C., \& Tozoğlu, E. (2009). Investigation of university students' internet addiction levels in terms of sports and different variables. Journal of Sports Education, 3(3), 102-1 18.

Cavusoglu., G., Yılmaz, A. K., Kabadayı, M., Abacı, S., \& Tasmektepligıl, M. (2017). Comparison of narcissism levels of students in the faculty of sports sciences in terms of some demographic variables. Turkish Journal of Sport and Exercise, 19(2), 150-156.

Cengizhan, C. (2005). A new dimension in students' computer and internet usage: “Internet Addiction”. Marmara University Atatïrk Faculty of Education Journal of Educational Sciences, 22(22), 83-98.

Chou, C., \& Hsiao, M.-C. (2000). Internet addiction, usage, gratification, and pleasure experience: The Taiwan college students' case. Computers \& Education, 35(1), 65-80.Available at: https://doi.org/10.1016/s0360-1315(00)00019-1.

Chou., C., Condron, L., \& Belland, J. C. (2005). A review of the research on Internet addiction. Educational Psychology Revierw, 17(4), 363-388.

Davis, R. A. (2001). A cognitive-behavioral model of pathological Internet use. Computers in Human Behavior, 17(2), 187-195.Available at: https://doi.org/10.1016/s0747-5632(00)00041-8.

Dever, A. (2010). Sports sociology. Istanbul: Title Publications.

Dogan., E., Yilmaz, A. K., Kabadayi, M., \& Mayda, M. H. (2018). An investigation of socialization and happiness levels of students studying in different faculties with sports science students. Journal of Kafkas University Institute of Social Sciences, 22(1), 403-41 1.

Goldberg, I. (1995). Internet addiction disorder-Diagnostic criteria. [Documento WWW]. Internet Addiction Support Group (IASG).

Günüç, S., \& Kayri, M. (2010). Internet addiction profile in Turkey and the development of internet addiction scale: A validity-reliability study. Hacettepe University Faculty of Education Journal, 39(39), 220-232. 
Jiang, Q. (2014). Internet addiction among young people in China: Internet connectedness, online gaming and academic performance decrement. Internet Research, 2, 20-24.

Kabadayı., M., Yılmaz, A. K., \& Mayda, H. M. (2018). Investigation of social self-efficacy levels of the students of the faculty of sport sciences. Kır, I., \& Sulak, S. (2014). Investigation of internet addiction levels of students of the faculty of education. Electronic Journal of Social Studies, $13(51), 150-167$.

Kraut, R., Patterson, M., Lundmark, V., Kiesler, S., Mukophadhyay, T., \& Scherlis, W. (1998). Internet paradox: A social technology that reduces social involvement and psychological well-being? American Psychologist, 53(9), 1017-1031.Available at: https://doi.org/10.1037/0003-066x.53.9.1017.

Leung, L. (2004). Net-generation attributes and seductive properties of the internet as predictors of online activities and internet addiction. Cyberpsychology \& Behavior, 7(3), 333-348.Available at: https://doi.org/10.1089/1094931041291303.

Lin, S. S., \& Tsai, C.-C. (2002). Sensation seeking and internet dependence of Taiwanese high school adolescents. Computers in Human Behavior, 18(4), 411-426.Available at: https://doi.org/10.1016/s0747-5632(01)00056-5.

Morahan-Martin, J., \& Schumacher, P. (2000). Incidence and correlates of pathological Internet use among college students. Computers in Human Behavior, 16(1), 13-29.Available at: https://doi.org/10.1016/s0747-5632(99)00049-7.

Nalwa, K., \& Anand, A. P. (2003). Internet addiction in students: A cause of concern. Cyber Psychology \& Behavior, 6(6), 653-656.

Özdemir, G. (2016). Evaluation of the relationship between internet addiction and depression in nineteen may university medical school students (Specialist Thesis). Ankara University Faculty of Medicine, Department of Family Medicine, Ankara.

Ozgen, F., \& Bavli, O. (2017). Examining the relationship between internet addiction and personality in university students. International Journal of Sport, Exercise \& Training Sciences, 3(4), 129-141.

Scherer, K. (1997). College life online of college life and development. Healthy and Unhealthy Internet Use Journal, 38(6), 655-665.

Song, I., Larose, R., Eastin, M. S., \& Lin, C. A. (2004). Internet gratifications and Internet addiction: On the uses and abuses of new media. Cyberpsychology \& Behavior, 7(4), 384-394.Available at: https://doi.org/10.1089/cpb.2004.7.384.

Soydan, Z. M. (2015). The relationship between university students' internet addiction and depression and life satisfaction (Master's Thesis). Haliç University Institute of Social Sciences Applied Psychology Program, Department of Psychology, Istanbul.

Subrahmanyam, K., \& Lin, G. (2007). Adolescents on the net: Internet use and well-being. Adolescence, 42(1), 659-677.

Tekeli., S. C. (2017). Comparison of social appearance anxiety and academic self-efficacy levels of physical education and sports teacher candidates and other teacher candidates. Master's Thesis. Bartin University. Institute of Educational Sciences.

Wang, W. (2001). Internet dependency and psychosocial maturity among college students. International Journal of Human-Computer Studies, 55(6), 919-938.Available at: https://doi.org/10.1006/ijhc.2001.0510.

Willoughby, T. (2008). A short-term longitudinal study of Internet and computer game use by adolescent boys and girls: Prevalence, frequency of use, and psychosocial predictors. Developmental Psychology, 44(1), 195-204.Available at: https://doi.org/10.1037/00121649.44.1.195.

Young, K. S. (1996). Psychology of computer use: XL. Addictive use of the Internet: A case that breaks the stereotype. Psychological Reports, 79(3), 899-902.Available at: https://doi.org/10.2466/pro.1996.79.3.899.

Young., K. S. (1997). What makes the internet addictive: Potential explanations for pathological internet use. Paper presented at the Paper Presented at the 105th Annual Conference of the American Psychological Association.

Young., K. S. (1998). Internet addiction: The emergence of a new clinical disorder. Cyber Psychology \& Behavior, 1(3), $237-244$.

Yuen, C. N., \& Lavin, M. J. (2004). Internet dependence in the collegiate population: The role of shyness. Cyberpsychology $\mathcal{E}^{\circ}$ Behavior, 7(4), 379-383.Available at: https://doi.org/10.1089/cpb.2004.7.379. 